\title{
Design and Development of Flexible Vacuum Clamping System for Thin Walled Cylindrical Object for CNC Machines
}

\section{Manzoor $\mathrm{T}^{1^{*}}$, Khalil $\mathrm{S}^{2}$, Khan $\mathrm{I}^{2}$, Gohar $\mathrm{GA}^{1}$ and Abid $\mathrm{M}^{3}$}

${ }^{1}$ Department of Mechanical Engineering, COMSATS Institute of Information Technology, Sahiwal, Pakistan

${ }^{2}$ Department of Mechanical and Aeronautical Engineering, University of Engineering and Technology, Taxila, Pakistan

${ }^{3}$ Interdisciplinary Research Centre, COMSATS Institute of Information Technology, Wah, Pakistan

\begin{abstract}
In this article, vacuum pressure for holding thin walled cylindrical object in vacuum clamping system on a computer numerical control machine (CNC) is studied. In this work, thin walled cylindrical object in vacuum clamping system is designed and different parameters for the vacuum clamping system are calculated. CNC rolling and flow farming machines are being employed for the thin wall and complicated objects. It is very challenging to make various thickness thin walled objects at high precision with help of jig and fixture at large scale. A lot of time is consumed for non-operational activities and skilled operator is required. In this work, this problem is resolved by replacing the machines built with 3-jaws hydraulic chucks with traditional made flexible clamping system. It would increase production rate and accuracy of object as compared to other conventional manufacturing processes. Designing imprecision may lead to process tolerance that caused to enhance manufacturing expenditure. In this work, optimum cutting parameters: feed rate, surface roughness and depth of cut of vacuum clamping system are deliberated. The main focus of this research is to design alternate clamping system for holding thin walled work piece with variable thickness and to save time, men power and raw material.
\end{abstract}

Keywords: Vacuum clamping system; CNC; Feed rate; Depth of cut; Surface roughness

\section{Introduction}

In contemporary manufacturing processes, high-dimensional accuracy and fine surface finishing play significant role. Accurate dimension is not conceivable to achieve by manual cutting. CNC machines are used for automation of machining process for massive production. Different machining operations can be finished on CNC machines that caused to increase productivity, improved quality, reduce the scrape rate, reliable and safe operation.

Chuck system in CNC for work pieces, machine tools which has a series of vacuum pods for safe degree of clearance during machining operation through the work piece. These additional pods are arranged around work table just like array. Pressure regulated by the selected pods to rise above the table to support the wok piece, without offering any interference to the operation of the cutting tool [1]. Utilization of vacuum pressure for holding of work pieces for machining that is provided the support to work piece between the lower surface of the work piece and the non-planar surface of the bed [2]. It was described that the designing and assembling of a custom vacuum chucks for lathe including a vacuum connector assembly which is mounted within the spindle bore of a lathe machine. Such type of vacuum chucks was utilized in wood turning lathe. The end face plate of the vacuum chuck can be altered to accommodate the variety of styles making it flexible [3]. It was described that positionable vacuum clamping system includes a vacuum table and one or more positionable vacuum clamps which can hold different shape of work pieces. It contains of base plate, positionable center plate and attached top plate sliding secured by a retainer washer to the base plate. Vacuum passages within and about the positionable vacuum clamp communicate between the vacuum table and the upper vacuum mating structure of the top plate to vacuuming a work piece to the top plate for subsequent machining by machine tool [4]. Comparative study of both improved and new clamping mechanisms for CNC lathes can be used for better cutting speed and better surface roughness. The most effective clamping mechanism for holed workpiece is ball compensators which provide better centrifugal forces [5]. It was concluded that minimum clamping force is calculated for dynamic stability of workpiece during different machining operation. Static and dynamic modal for determining the optimal set of clamping force was solved by using the particle swarm optimization (PSO) technique highlighting computational intelligence [6]. By means of theoretical calculation, hydraulic clamping system for CNC Machine was designed for safety and reliability of workpiece such as guide disc. The machine has not only acquired the national utility models patent but also has been put into production [7]. It was presented a prediction model of a workpiece for geometric inaccuracy and setup error for fixture with one or more locating surface. Machining error can be predicted due to locating error on a multi-body system and homogeneous transfer matrix. Cutting test modal is effective and practicable [8]. The finite element method technique was applied to support modeling work. Chuck stiffness and critical bending force can be enhanced by clamping length [9]. For high cutting speed, greater spindle speed of machines is required. The theoretical modal was presented for conventional and modern chuck that ensures a safe highspeed turning process, and makes it conceivable to completely utilize the potential of jaw-chucks at high rotational speeds [10]. Optimal machining parameters were obtained for turning cylindrical stocks into continuous finished profile using six non-traditional techniques (GA, SA, TS, ACO, MA and PSO) that for reducing manufacturing cost in profile turning [11]. It was concluded that increase feed rate that due to cause of cutting force. Increase negative tool rake angle and cutting speed as to decrease of tool chip friction [12]. It was concluded that the better surface finish may be acquired by turning carbon alloy steels at low feed rate and high spindle

*Corresponding author: Manzoor T, Department of Mechanical Engineering COMSATS Institute of Information Technology, Sahiwal, Pakistan, Tel: +923225294885; E-mail: tareqmanzoor@hotmail.com

\section{Received May 09, 2017; Accepted June 30, 2017; Published July 04, 2017}

Citation: Manzoor T, Khalil S, Khan I, Gohar GA, Abid M (2017) Design and Development of Flexible Vacuum Clamping System for Thin Walled Cylindrical Object for CNC Machines. J Appl Mech Eng 6: 271. doi: 10.4172/21689873.1000271

Copyright: (c) 2017 Manzoor T, et al. This is an open-access article distributed under the terms of the Creative Commons Attribution License, which permits unrestricted use, distribution, and reproduction in any medium, provided the original author and source are credited. 
Citation: Manzoor T, Khalil S, Khan I, Gohar GA, Abid M (2017) Design and Development of Flexible Vacuum Clamping System for Thin Walled Cylindrical Object for CNC Machines. J Appl Mech Eng 6: 271. doi: 10.4172/2168-9873.1000271

Page 2 of 10

speeds. The study exposes that the surface roughness is directly influenced by the spindle speed and feed rate. It is observed that the surface roughness increases with increased feed rate and is higher at lower speeds and vice versa for all feed rates [13]. It was experimentally determined that material removal rate in CNC turning process is influenced by cutting speed and depth of cut. Surface roughness $(\mathrm{Ra})$ is influenced by Feed rate and nose radius of tools. Optimization of Surface roughness $(\mathrm{Ra})$, material removal rate (MRR) and depth of cut is the most significant parameter affecting the performance followed by the nose radius [14]. Surface roughness profile depends of feed rate. Increase in roughness is generally measured to be a function of square of the feed rate. At low feed rate the micro roughness is more seen in the existence of several frequencies. Chip thickness and coil radius increase with increase in feed rate. The roughness appear like a screw thread profile representing chip removal to be the dominant mechanism of roughness generation at high feed rate [15]. Surface roughness is known to be inversely proportional to cutting speed but directly proportion of feed rate. Surface roughness is proportional to depth of cut and inversely proportional to nose radius [16].

\section{Experimental Setup}

\section{CNC specification}

In this study, JOHNFORD SL-60 CNC Lathe machine is used. It has built-in 3-jaws hydraulic chuck with all accessories, in which 3-jaws hydraulic chuck was exchanged with vacuum clamping system for experimentation.

\section{Chuck measurement}

It is necessary to find out dimension of chuck assembly because vacuum clamping system is adjusted on this chuck assembly with accurate dimension. Chuck measurement of different component is taken in Table 1.

Hydraulic chuck is mounted on chuck base plate. Figure 1 indicates three pair of bolts which is in between jaws. These bolts were loosed through device and separated hydraulic chuck from base plate as shown in Figure 2. It showed front view of base plate where clamping system would be installed. Figure 3 indicated the side view of base plate where new vacuum clamping system to be installed.

\section{Flexible vacuum clamping system}

There are different components of vacuum clamping system which were discussed below. It has following different machines parts:

Chuck base: Chuck base is main component of vacuum clamping system which receives and retains vacuum pressure. Proper materials selection for chick base plate is necessary to attain required pressure for experimentation. Mild steel were used with desirable mechanical properties such as hardness, tensile strength and Impact strength. Some material properties are shown in the Table 2. Required hardness, tensile strength and impact strength can be attained through heat treatment mechanism. Micro structural analysis was carried out through scanning electron microscopic. Micrograph exhibits proper materials division and stability of grain structure. SEM image was taken as X500 up-to 10 $\mu \mathrm{m}$ Scale (Figures 4). Mechanical design was prepared through solid

\begin{tabular}{|c|c|}
\hline Description & Value \\
\hline Chuck diameter & $300 \mathrm{~mm}$ \\
\hline Total chuck height & $250 \mathrm{~mm}$ \\
\hline Length of the tensioning tube & $1500 \mathrm{~mm}$ \\
\hline X-axis travel & $250 \mathrm{~mm}$ \\
\hline Z-axis travel & $900 \mathrm{~mm}$ \\
\hline
\end{tabular}

Table 1: Chuck measurements.

\begin{tabular}{|c|c|}
\hline Item & Description \\
\hline Material & Mild steel \\
\hline Hardness requirement & $15 \sim 18 \mathrm{HRC}$ \\
\hline Material porosity & Radiographic testing \\
\hline Tensile strength & $400 \mathrm{~N} / \mathrm{mm}^{2}$ \\
\hline Impact strength & 75 Joules (IZOD) \\
\hline
\end{tabular}

Table 2: Chuck base properties.

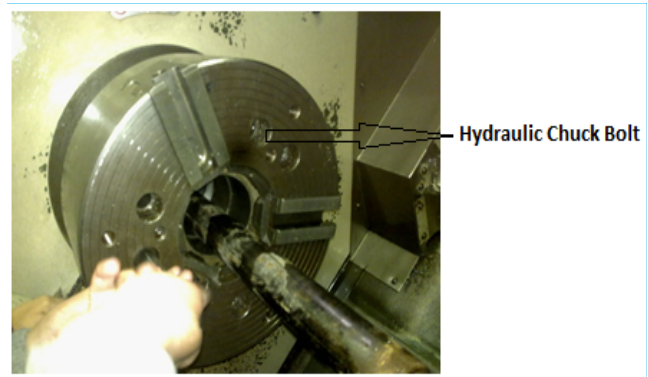

Figure 1: Hydraulic chuck.

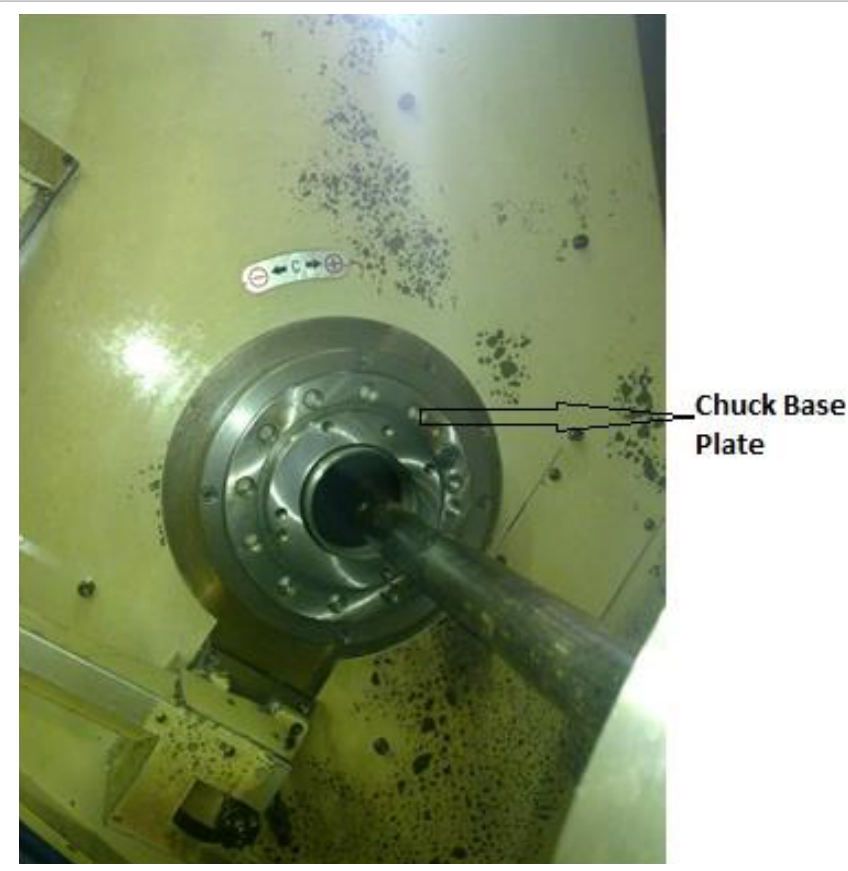

Figure 2: Hydraulic chuck base plate.

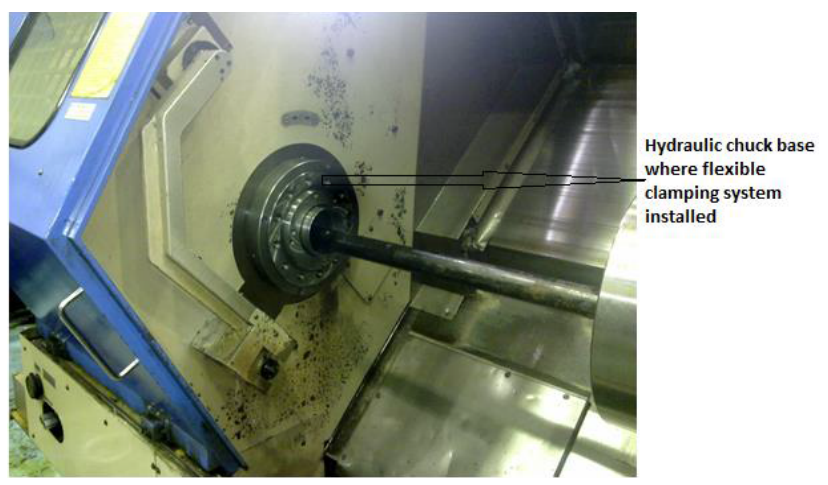

Figure 3: Base plate where clamping system to be installed. 
Citation: Manzoor T, Khali S, Khan I, Gohar GA, Abid M (2017) Design and Development of Flexible Vacuum Clamping System for Thin Walled Cylindrical Object for CNC Machines. J Appl Mech Eng 6: 271. doi: 10.4172/2168-9873.1000271

Page 3 of 10

work according to our requirements as shown in Figures 5 and 6 . The chuck base plate has six bolts which were fitted on Machine's inbuilt chuck assembly base.

Front holding plate: A good design of front holding plate is suitable for better machining operation. It has ability to hold the thin walled cylindrical work piece in suitable position and provide sufficient vacuum on the surface of the work piece for proper clamping and holding during the machining processes. Front plate materials specification is given in Table 3. The front holding plate is an essential portion in the whole structure design, because the this plate is responsible to clamp the thin walled cylindrical work piece in better adjustment and deliver appropriate vacuum on the surface of the work piece for suitable compressing in operational processes. Figure 7 represents the work piece is fitted in front holding plate (Figure 7).

\section{Production Method}

\section{Conventional manufacturing method}

Manufacturing of complicated objects with CNC machines increases the production rate and quality of products. In this method, there are five different machining steps for acquiring the final products. In each and every step, different tools and inserts are used for performing operation functions.

This research work comprises on practical solution for getting an alternate more flexible and precise clamping mechanism that is used to clamp properly the highly critical and precise thin walled cylindrical work piece for its machining operation (Tables 4 and 5).

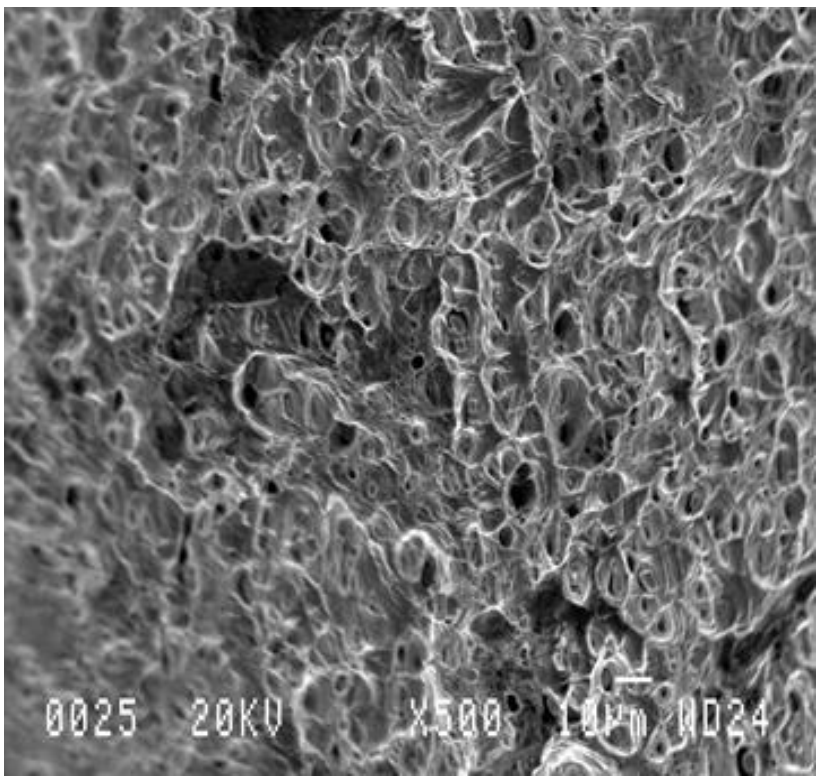

Figure 4: Microscopic view of materials.

\begin{tabular}{|c|c|}
\hline Item & Description \\
\hline Material & Aluminum \\
\hline Hardness requirement & $\sim 15 \mathrm{HB}$ \\
\hline Material porosity & Radiographic testing \\
\hline Tensile strength & $60 \mathrm{~N} / \mathrm{mm}^{2}$ \\
\hline Impact strength & $27 \mathrm{Joules}$ \\
\hline
\end{tabular}

Table 3: Front plate materials specification.

\begin{tabular}{|c|c|c|c|}
\hline Process code & Process & $\begin{array}{c}\text { Cutting tools and } \\
\text { geometry }\end{array}$ & Process time $\mathbf{t}_{\mathbf{p}}$ min \\
\hline$A_{1}$ & Blank cutting & Band saw & $60 \mathrm{~min}$ \\
\hline$B_{1}$ & Outer stepping & CNMG 160608 & $150 \mathrm{~min}$ \\
\hline $\mathrm{C}_{1}$ & Inner rough/finish & $\begin{array}{c}\text { DCMT 150408 TP } \\
2000\end{array}$ & $100 \mathrm{~min}$ \\
\hline $\mathrm{D}_{1}$ & Outer rough/finish & VCGR 160408 CP 200 & $90 \mathrm{~min}$ \\
\hline $\mathrm{E}_{1}$ & $\begin{array}{c}\text { Outer collar } \\
\text { milling }\end{array}$ & $\begin{array}{c}\text { Dormer HSS End mill } \\
\text { dia 10 }\end{array}$ & $30 \mathrm{~min}$ \\
\hline
\end{tabular}

Table 4: Different machining operations and process codes.

\begin{tabular}{|c|c|c|c|}
\hline Process code & Feed rate f, mm/rev & n, rpm & $\begin{array}{c}\text { Depth of } \\
\text { cut ap, } \mathbf{~ m m}\end{array}$ \\
\hline $\mathrm{A}_{1}$ & \multicolumn{2}{|c|}{ Band saw } \\
\hline $\mathrm{B}_{1}$ & 0.4 & 1000 & 0.8 \\
\hline $\mathrm{C}_{1}$ & 0.1 & $400 \sim 1200$ & 0.1 \\
\hline $\mathrm{D}_{1}$ & 0.25 & $200 \sim 600$ & 0.2 \\
\hline $\mathrm{E}_{1}$ & 0.8 & 1000 & 2.0 \\
\hline
\end{tabular}

The dimension of the work piece under consideration is as under;

Blank thickness $\left(\mathrm{B}_{\mathrm{T}}\right)=45.00 \mathrm{~mm}$

Maximum profile thickness $\left(\mathrm{P}_{\mathrm{tmax}}\right)=2.53 \mathrm{~mm}$

Minimum profile thickness $\left(\mathrm{P}_{\mathrm{tmin}}\right)=1.25 \mathrm{~mm}$

Profile Centre height $\left(\mathrm{P}_{\mathrm{CH}}\right)=37.00 \mathrm{~mm}$

Outer diameter final $\left(\mathrm{OD}_{\mathrm{F})}=210 \mathrm{~mm}\right.$

Total time $\mathrm{T}_{\mathrm{t}=} \mathrm{t}_{\mathrm{p} 1}+\mathrm{t}_{\mathrm{p} 2}+\mathrm{t}_{\mathrm{p} 3}+\mathrm{t}_{\mathrm{p} 4}+\mathrm{t}_{\mathrm{p} 5}$

$=60+150+100+90+30$

$=430 \mathrm{~min}$

Non-conventional operation $\mathrm{T}=50 \mathrm{~min}$

Work piece per shift $\_8 \times 60 / 480$

$=1 \sim 1 \mathrm{Pc} /$ Shift

$=60$ Pcs $/$ Month

$\mathrm{V}_{\mathrm{c}_{1 \& 2}}=\frac{\mathrm{n} \times \pi \times \mathrm{D}_{\mathrm{c}}}{1000}$

Cutting Speed, $\mathrm{Vc}_{1}$ andVc for Process $\mathrm{C}_{1}$ and $\mathrm{D}_{1}$ respectively has been calculated through equation 1 . During this operation, machine is operated on $400 \mathrm{rpm}$ for inner rough $\left(\mathrm{C}_{1}\right)$ and $200 \mathrm{rpm}$ for outer profile $\left(\mathrm{D}_{1}\right)$ and worked on workpiece of $200 \mathrm{~mm}$ diameter. Cutting speed for inner profile $\mathrm{Vc}_{1}$ and outer rough $\mathrm{Vc}_{2}$ are $251.2 \mathrm{~m} / \mathrm{min}$ and $125.6 \mathrm{~m} / \mathrm{mm}$ respectively.

In turning of the inner profile of the work piece, G96 command is used which stands for constant surface speed parameter. The format of the G96 command is as: G96 S (surface cutting speed) (Figure 8).

$$
\mathrm{R}_{\mathrm{a}_{1 \& 2}}=\frac{\mathrm{f}^{2} \times 50}{\mathrm{r}_{\varepsilon}}
$$

Surface finish, $\mathrm{Ra}_{1}$ and $\mathrm{Ra}_{2}$ for process $\mathrm{C}_{1}$ and $\mathrm{D}_{1}$ respectively has been calculated through equation 2 . During this operation, machine is operated with feed rate $0.1 \mathrm{~mm} / \mathrm{rev}$ and nose radius $(\mathrm{r \varepsilon}) 0.8 \mathrm{~mm}$ for process $\mathrm{C}_{1}$ and feed rat $0.25 \mathrm{~mm} / \mathrm{rev}$ and nose radius $(\mathrm{r} \varepsilon) 0.8 \mathrm{~mm}$ for Process $\mathrm{D}_{1}$. Surface finish for inner profile $\mathrm{Ra}_{1}$ and outer profile $\mathrm{Ra}_{2}$ are $0.625 \mu \mathrm{m}$ and $3.90 \mu \mathrm{m}$ respectively

$$
\mathrm{R}_{\mathrm{t}_{\mathrm{L} \& 2}}=\mathrm{k} \frac{\mathrm{f}^{2} \times 100}{8 \times \mathrm{r}_{\varepsilon}}
$$


Citation: Manzoor T, Khalil S, Khan I, Gohar GA, Abid M (2017) Design and Development of Flexible Vacuum Clamping System for Thin Walled Cylindrical Object for CNC Machines. J Appl Mech Eng 6: 271. doi: 10.4172/2168-9873.1000271

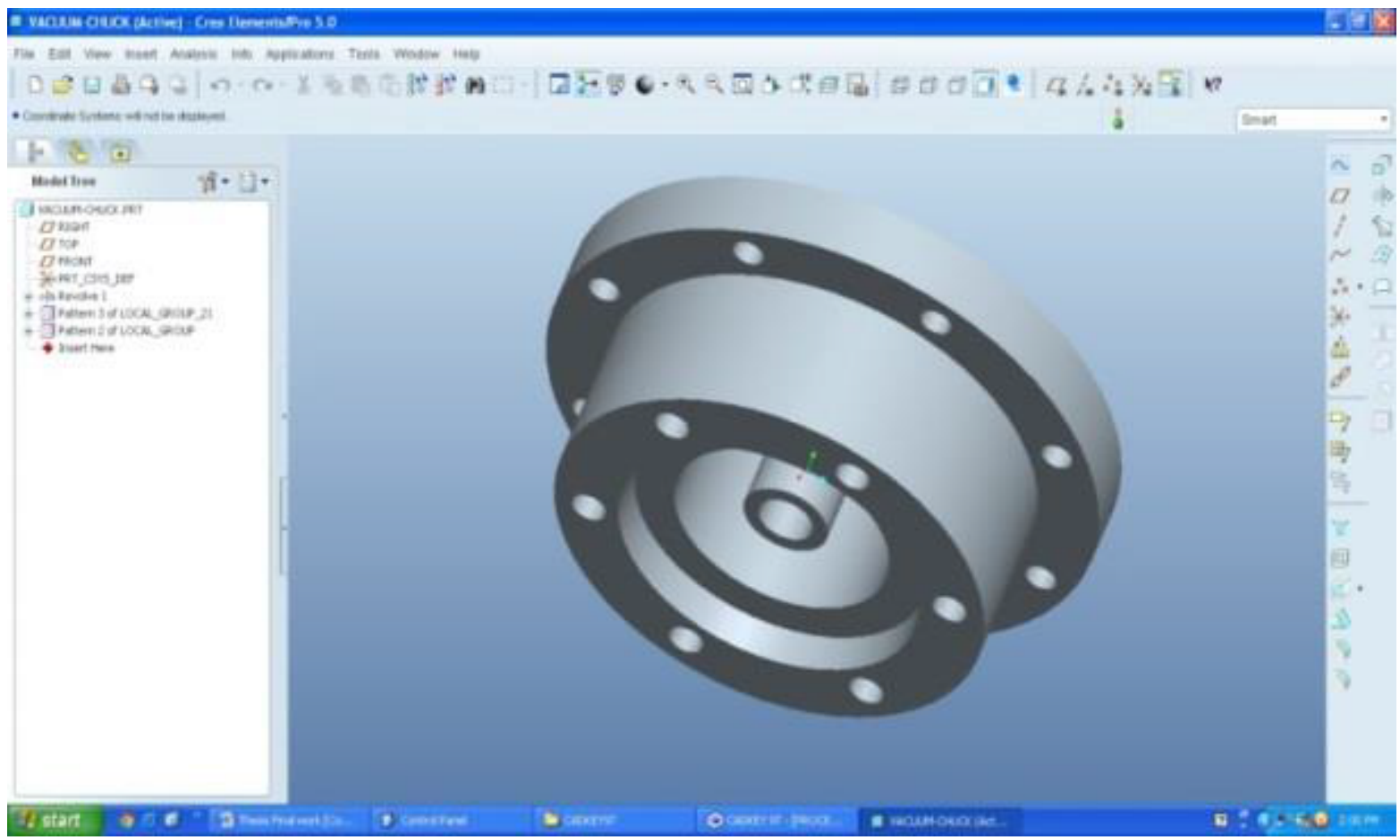

Figure 5: Vacuum chuck front side drawing.

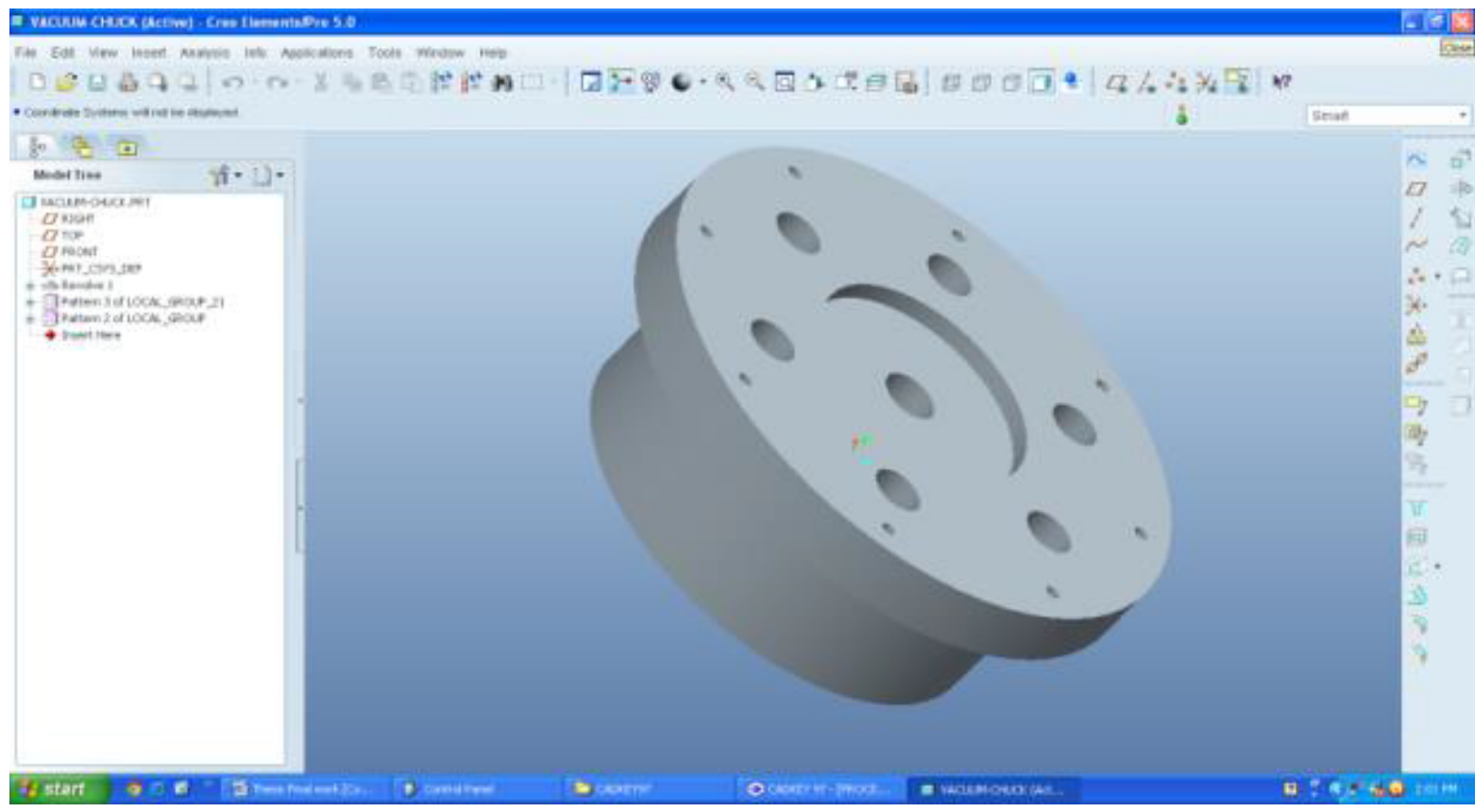

Figure 6: Vacuum chuck back side drawing.

Profile depth, $\mathrm{Rt}_{1}$ and $\mathrm{Rt}_{2}$ for process $\mathrm{C}_{1}$ and $\mathrm{D}_{1}$ respectively have been calculated through equation 3. During this operation, machine is operated with feed rate $0.1 \mathrm{~mm} / \mathrm{rev}$ and nose radius $(\mathrm{r \varepsilon}) 0.8 \mathrm{~mm}$ for process $\mathrm{C}_{1}$ and feed rat $0.25 \mathrm{~mm} / \mathrm{rev}$ and nose radius $(\mathrm{r} \varepsilon) 0.8 \mathrm{~mm}$ for process $\mathrm{D}_{1}$ with $\mathrm{k}=1.4$ for steels and stainless steel. Profile depth for inner profile $\mathrm{Rt}_{1}$ and outer profile $\mathrm{Rt}_{2}$ are $0.2185 \mu \mathrm{m}$ and $1.3671 \mu \mathrm{m}$ respectively.
$\mathrm{Q}_{1 \& 2}=\mathrm{V}_{\mathrm{c}_{1}} \times \mathrm{f} \times \mathrm{a}_{\mathrm{p}}$

Metal removal rate, $\mathrm{Q}_{1}$ and $\mathrm{Q}_{2}$ for Process $\mathrm{C}_{1}$ and $\mathrm{D}_{1}$ respectively has been calculated through equation 4 . During this operation, machine is operated with feed rate $0.1 \mathrm{~mm} / \mathrm{rev}$, cutting speed $\left(\mathrm{Vc}_{1}\right) 251.2 \mathrm{~m} / \mathrm{min}$ and depth of cut (ap) $0.1 \mathrm{~mm}$ for process $\mathrm{C} 1$ and feed rate $0.25 \mathrm{~mm} / \mathrm{rev}$, cutting speed (Vc2) $125.66 \mathrm{~m} / \mathrm{min}$ and depth of cut (ap) $0.2 \mathrm{~mm}$ for Process D1. 
Citation: Manzoor T, Khali S, Khan I, Gohar GA, Abid M (2017) Design and Development of Flexible Vacuum Clamping System for Thin Walled Cylindrical Object for CNC Machines. J Appl Mech Eng 6: 271. doi: 10.4172/2168-9873.1000271

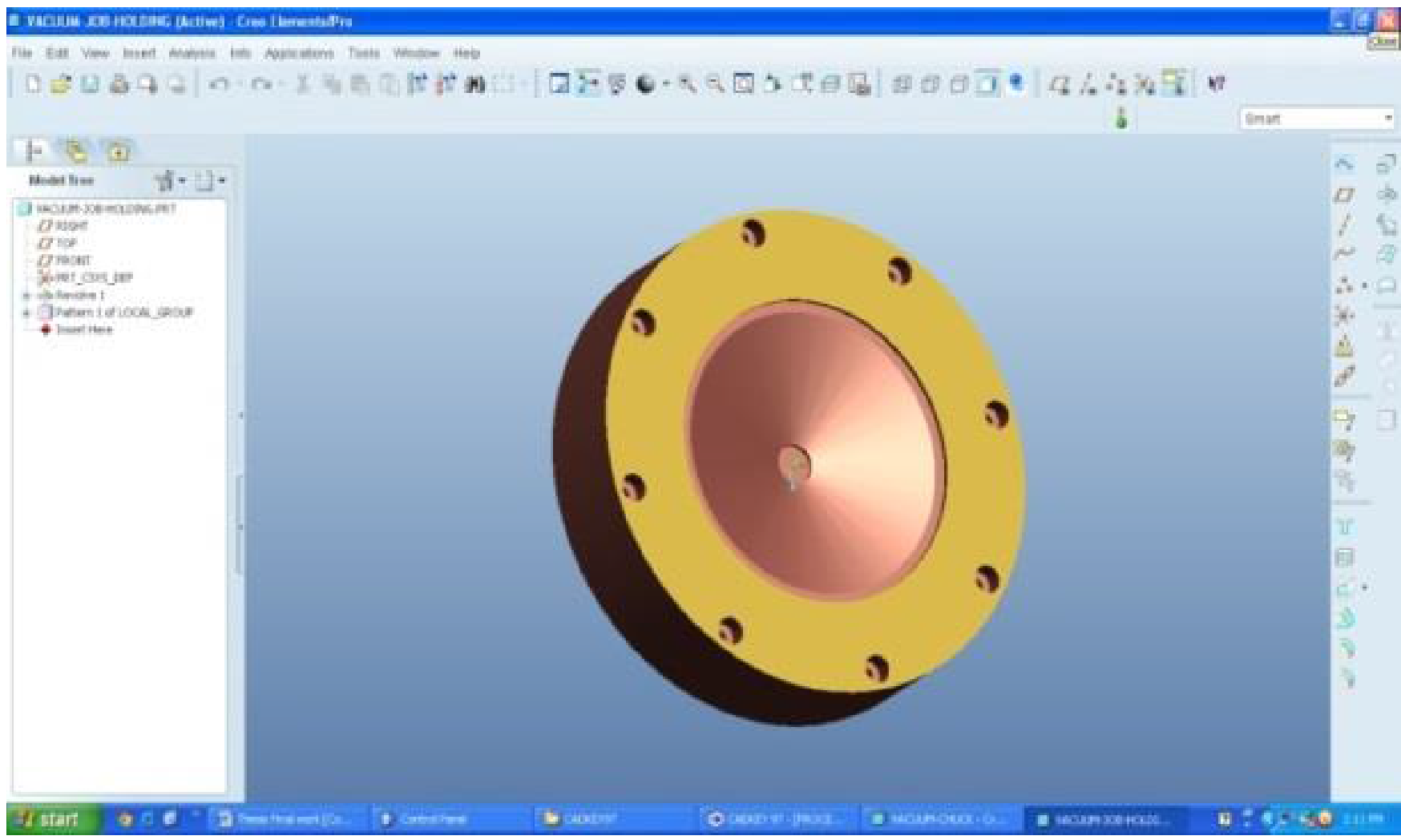

Figure 7: Front holding plate.
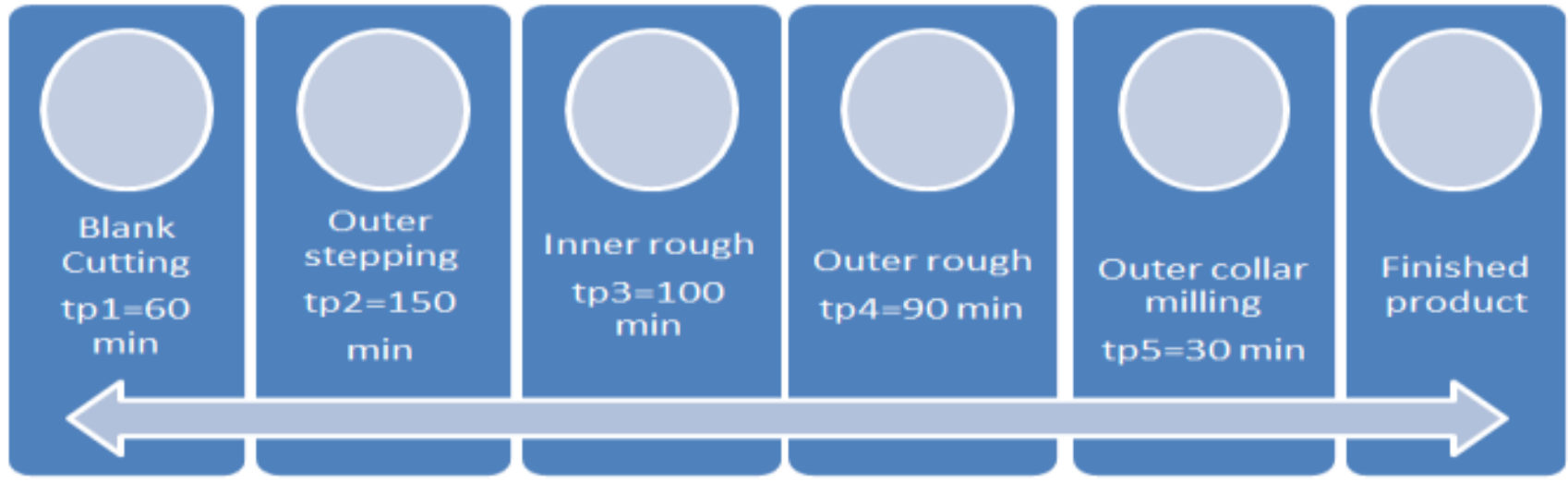

Figure 8: Machining operation time.

Metal removal rate $\mathrm{Q}_{1}$ and $\mathrm{Q}_{2}$ are $2.512 \mathrm{~cm}^{3} / \mathrm{min}$ and $6.283 \mathrm{~cm}^{3} / \mathrm{min}$ respectively.

The quality control standards for surface finish ranges for inner and outer profiles are as follows:

Inner Profile $=0.5 \mu \mathrm{m}$ to $2 \mu \mathrm{m}=\mathrm{Ra}_{1}$

Outer Profile $=3 \mu \mathrm{m}$ to $6 \mu \mathrm{m}=\mathrm{Ra}_{2}$

There were taken 10 random samples from the monthly production to check the quality of the final thin walled work piece (Table 6).

In conventional manufacturing process, work piece is rejected due to following reasons:

\begin{tabular}{|c|c|c|c|}
\hline Sample no, $\mathbf{n}$ & $\begin{array}{c}\text { Measured values } \\
\mathbf{R a}_{\mathbf{1}}, \boldsymbol{\mu m}\end{array}$ & $\begin{array}{c}\text { Measured values } \\
\mathbf{R a}_{\mathbf{2}}, \boldsymbol{\mu m}\end{array}$ & Remarks \\
\hline $\mathrm{n}_{1}$ & 1.04 & $\mathbf{2 . 9 5}$ & Rejected \\
\hline $\mathrm{n}_{2}$ & 0.8 & $\mathbf{2 . 2 5}$ & Rejected \\
\hline $\mathrm{n}_{3}$ & 2.0 & 3.54 & Accepted \\
\hline $\mathrm{n}_{4}$ & 0.75 & 3.10 & Accepted \\
\hline $\mathrm{n}_{5}$ & 1.14 & 3.30 & Accepted \\
\hline $\mathrm{n}_{6}$ & $\mathbf{0 . 2 5}$ & 3.03 & Rejected \\
\hline $\mathrm{n}_{7}$ & 1.19 & 4.09 & Accepted \\
\hline $\mathrm{n}_{8}$ & $\mathbf{0 . 3 5}$ & $\mathbf{6 . 5 5}$ & Rejected \\
\hline $\mathrm{n}_{9}$ & 2.15 & 5.05 & Accepted \\
\hline $\mathrm{n}_{10}$ & 0.66 & 5.09 & Accepted \\
\hline
\end{tabular}

Table 6: Random sampling technique. 
Citation: Manzoor T, Khalil S, Khan I, Gohar GA, Abid M (2017) Design and Development of Flexible Vacuum Clamping System for Thin Walled Cylindrical Object for CNC Machines. J Appl Mech Eng 6: 271. doi: 10.4172/2168-9873.1000271

Page 6 of 10

1. Work piece is clamped at three different points that caused localized stresses at that region which may lead to rejection of it.

2. The carelessness of the operator during tightening of the work piece may lead to profile rejection, because unbalanced clamping of a thin walled work piece.

Analysis of the bolted ring/fixture is executed on ANSYS and shown in Figure 9.

\section{Flexible clamping system manufacturing}

Flexible clamping system has following objectives.

1. Material utilization has been reduced from $45 \mathrm{~mm}$ to $10 \mathrm{~mm}$ sheet and material saves 4 times as compared to conventional manufacturing process. It was attained nearest shape of materials as desired shape with help of pressing machines as shown in Figures 10 and 11.
2. Number of machining operations and time will be reduced that caused increase the rate of production.

3. Better surface and dimensional accuracy are attained as compared to old clamping techniques by using fixture, ring and bolts.

Vacuum clamping system has four steps to get final work piece (Table 7).

Total time $\mathrm{T}_{\mathrm{t}}=\mathrm{tp} 1+\mathrm{tp} 2+\mathrm{tp} 3+\mathrm{tp} 4=30+30+90+90$

$=240 \mathrm{~min}$

Non-conventional operation $\mathrm{T}=30 \mathrm{~min}$

Work piece per shift $=8 \times 60 / 270=1.78=2 \mathrm{Pc} / \mathrm{Shift}=120 \mathrm{Pcs} /$ Month (Table 8).

The quality control standards for surface finish ranges for inner and outer profiles are as follows

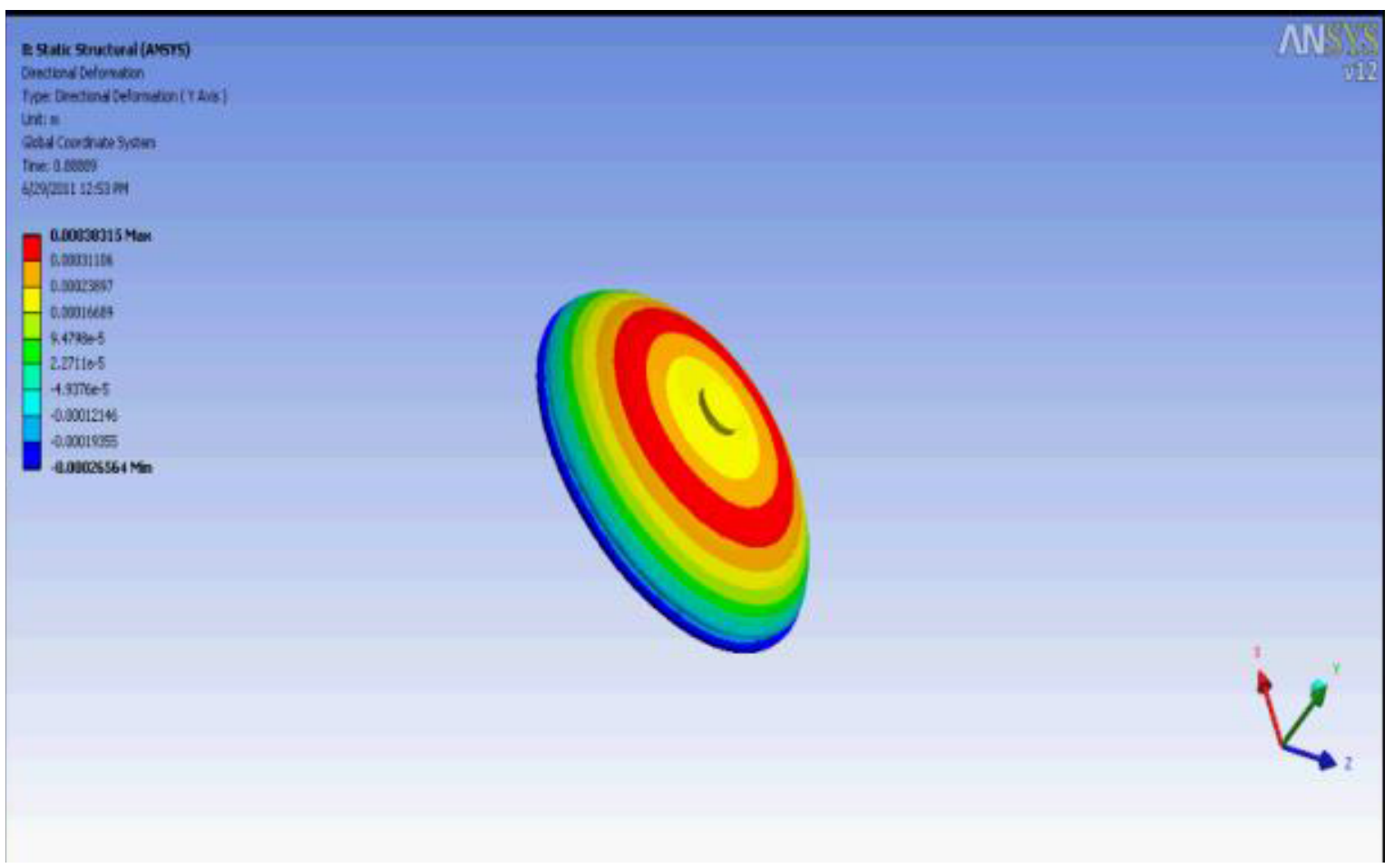

Figure 9: Analysis of conventional clamping system.

PRESSING FROM PLATE

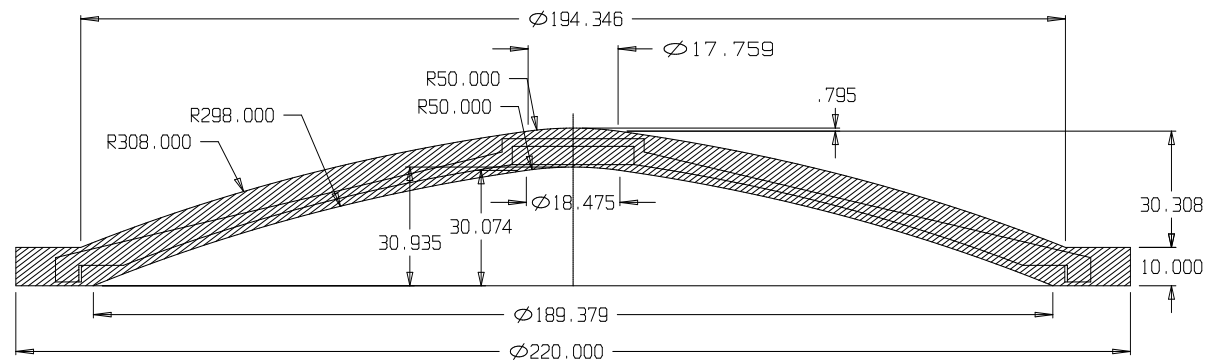

Figure 10: Desired shape after pressing. 

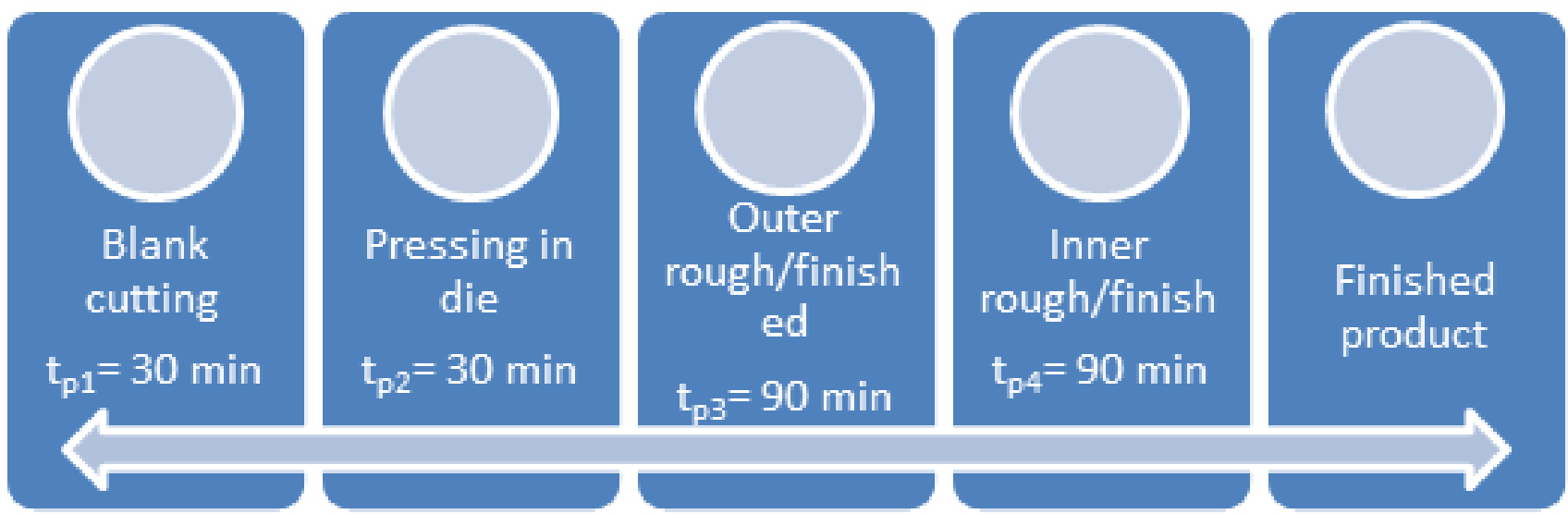

Figure 11: Time flow chart of different process.

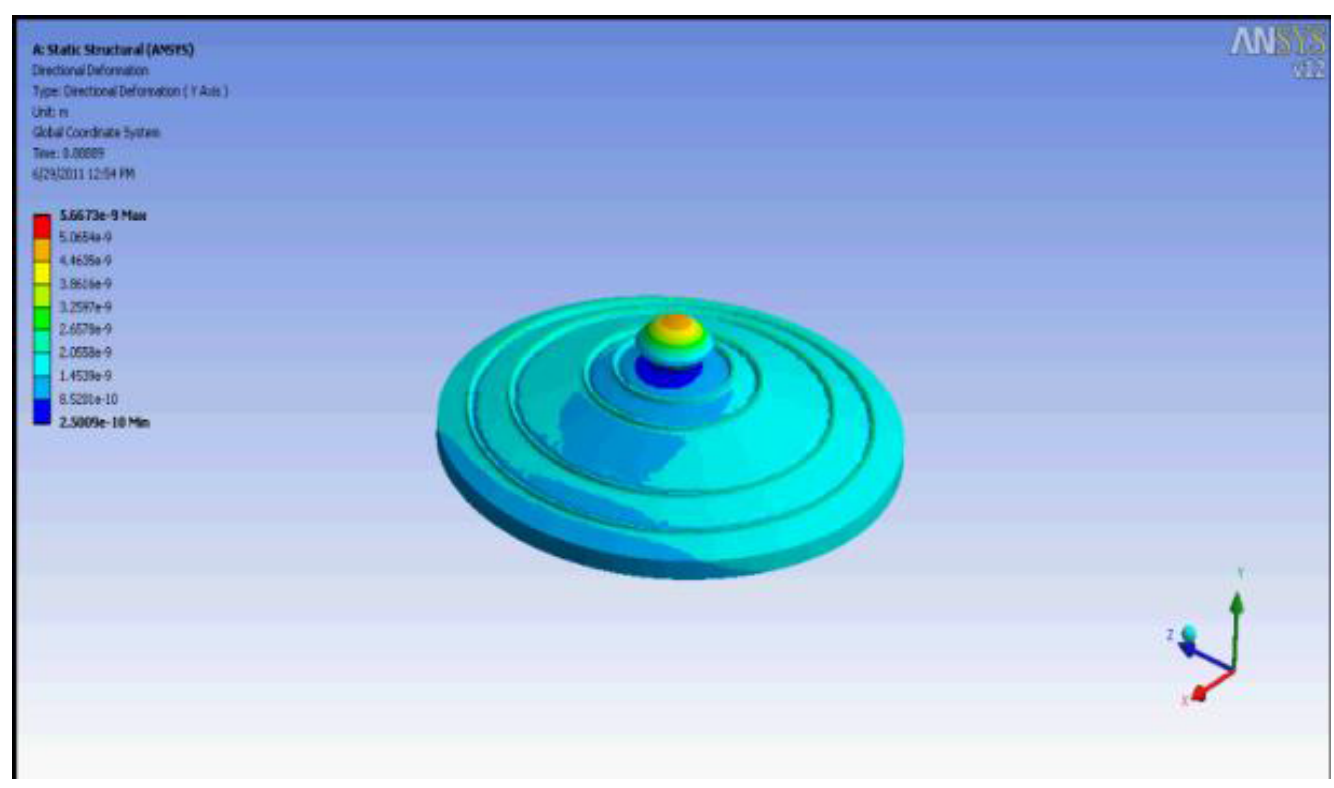

Figure 12: ANSYS analysis.

\section{Comparison of Old Conventional \& New Flexible Clamping Systems}

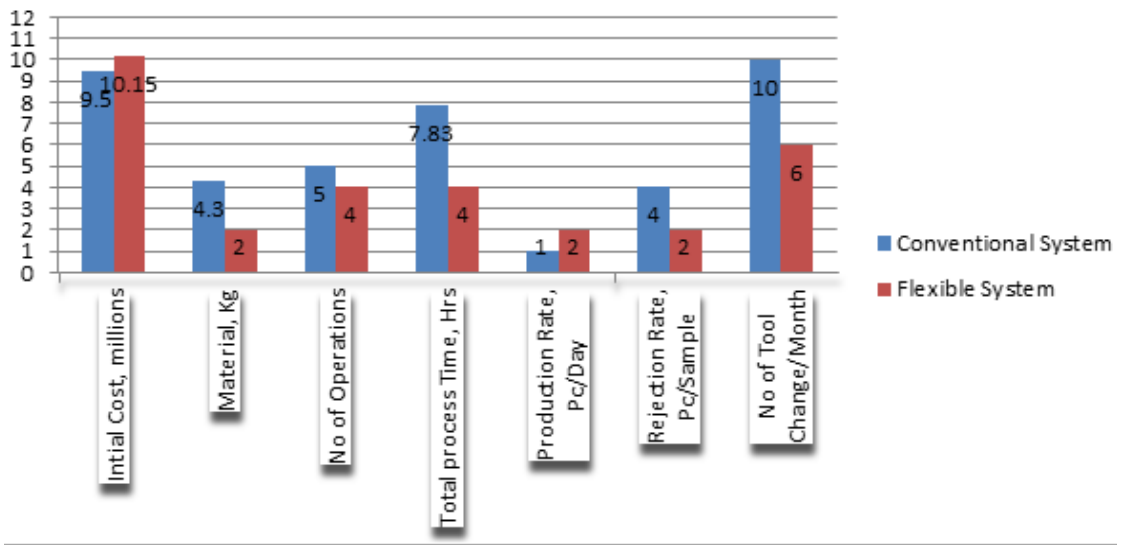

Figure 13: Graphical comparison. 


\begin{tabular}{|c|c|c|c|}
\hline Process code & Process & $\begin{array}{c}\text { Cutting tools and } \\
\text { geometry }\end{array}$ & $\begin{array}{c}\text { Process } \\
\text { time }_{\mathbf{p}} \mathbf{m i n}\end{array}$ \\
\hline $\mathrm{A}_{1}$ & Blank cutting & Band saw & $30 \mathrm{~min}$ \\
\hline $\mathrm{B}_{1}$ & Outer stepping & Pressing machine & $30 \mathrm{~min}$ \\
\hline $\mathrm{D}_{1}$ & Outer rough/finish & $\begin{array}{c}\text { DCMT 150408 TP } \\
2000\end{array}$ & $90 \mathrm{~min}$ \\
\hline $\mathrm{C}_{1}$ & Inner rough/finish & $\begin{array}{c}\text { VCGR 160408 } \\
\text { CP 200 }\end{array}$ & $90 \mathrm{~min}$ \\
\hline
\end{tabular}

Table 7: Different machining operations and process codes.

\begin{tabular}{|c|c|c|c|c|}
\hline $\begin{array}{c}\text { Process } \\
\text { code }\end{array}$ & Pressing in die & $\begin{array}{c}\text { Feed rate } \\
\mathbf{f}, \mathbf{m m} / \mathbf{r e v}\end{array}$ & $\mathbf{n}, \mathbf{r p m}$ & $\begin{array}{c}\text { Depth of } \\
\text { cut ap, } \\
\mathbf{m m}\end{array}$ \\
\hline $\mathrm{A}_{1}$ & Pressing in die & \multicolumn{3}{|c|}{ Pressing machine } \\
\hline $\mathrm{B}_{1}$ & Outer stepping & 0.4 & 1000 & 0.8 \\
\hline $\mathrm{D}_{1}$ & Outer rough/finish & 0.25 & $200 \sim 600$ & 0.2 \\
\hline $\mathrm{C}_{1}$ & Inner rough/Finish & 0.1 & $400 \sim 1200$ & 0.1 \\
\hline
\end{tabular}

Table 8: Cutting speed parameters.

Inner Profile $=0.5 \mu \mathrm{m}$ to $2 \mu \mathrm{m}=\mathrm{Ra}_{1}$

Outer Profile $=3 \mu \mathrm{m}$ to $6 \mu \mathrm{m}=\mathrm{Ra}_{2}$

There were taken 10 random samples from the monthly production to check the quality of the final thin walled work piece (Table 9).Analysis of the new flexible clamping system using vacuum pressure as the main holding force during machining is performed on ANSYS and shown in Figure 12.

\section{Production System Comparison}

The following table compares the old conventional method of production and the new flexible manufacturing system using vacuum. The whole month's data is compared for both the systems (Table 10).

\section{Optimum Parameters for Flexible Clamping System}

After installing the vacuum clamping system, the series of experiments are conducted to find out the optimum machining parameters such as feed rate, surface roughness and depth of cut (Figure 13).

\section{Optimum feed rate}

Optimum feed rate is calculated with the increase of feed rate and checkout surface roughness in outer and inner finish.

Optimum feed rate for process D1: Spindle RPM range is kept constant at 200 600 RPM and by changing feed rates from 0.2 to 0.45 $\mathrm{mm}$ (Table 11)

Surface roughness value is in acceptable range ( 3 to $6 \mu \mathrm{m})$ with feed rate vary from 0.2 to 0.25 . At feed rate 0.3 and 0.35 , the range is out. By increasing feed rate 0.4 , it is in acceptable range. This is our optimum value where surface roughness in acceptable range (Figures 14-18).

Optimum feed rate for process $\mathrm{C}_{1}$ : Spindle RPM range is kept constant at $400 \sim 1200 \mathrm{rev} / \mathrm{min}$ and by changing feed rates from 0.1 to $0.35 \mathrm{~mm}$ (Table 12)

Surface roughness value is in acceptable range $(0.5$ to $2 \mu \mathrm{m})$ at feed rate 0.1 to 0.15 . When we increase the feed rate to 0.2 and $0.25 \mathrm{~mm}$, the range is out. By increasing feed rate 0.3 , it is in acceptable range. This is our optimum value where surface roughness is in acceptable range.

\section{Optimum depth of cut}

Optimum depth of cut for process D1: At constant feed rate, surface finish changes with variation of depth of cut from 0.2 to 0.6 (Table 13).

\begin{tabular}{|c|c|c|c|}
\hline Sample No, $\mathbf{n}$ & $\begin{array}{c}\text { Measured values } \\
\mathbf{R a}_{\mathbf{1}}, \boldsymbol{\mu} \mathbf{m}\end{array}$ & $\begin{array}{c}\text { Measured values } \\
\mathbf{R a}_{\mathbf{2}}, \boldsymbol{\mu m}\end{array}$ & Remarks \\
\hline $\mathrm{n}_{1}$ & 1.04 & 3.15 & Accepted \\
\hline $\mathrm{n}_{2}$ & 0.8 & $\mathbf{2 . 2 5}$ & Rejected \\
\hline $\mathrm{n}_{3}$ & 1.90 & 3.30 & Accepted \\
\hline $\mathrm{n}_{4}$ & 0.75 & 3.19 & Accepted \\
\hline $\mathrm{n}_{5}$ & 1.19 & 4.18 & Accepted \\
\hline $\mathrm{n}_{6}$ & $\mathbf{0 . 3 5}$ & 2.80 & Rejected \\
\hline $\mathrm{n}_{7}$ & 1.29 & 4.27 & Accepted \\
\hline $\mathrm{n}_{8}$ & 0.95 & 5.15 & Accepted \\
\hline $\mathrm{n}_{9}$ & 2.15 & 5.22 & Accepted \\
\hline $\mathrm{n}_{10}$ & 2.67 & 5.09 & Accepted \\
\hline
\end{tabular}

Table 9: Random sampling technique.

\begin{tabular}{|c|c|c|}
\hline Description & Conventional system & Flexible system \\
\hline Initial cost, & 9.5 & 10.15 \\
\hline millions & & 2 \\
\hline Material, $\mathrm{Kg}$ & 5.3 & 4 \\
\hline No of operations & 7.83 & 4 \\
\hline Total process time, $\mathrm{h}$ & 5 & \\
\hline
\end{tabular}

Table 10: Systems comparison.

\begin{tabular}{|c|c|c|c|c|c|c|}
\hline $\begin{array}{c}\text { Job } \\
\text { dia }\end{array}$ & RPM (rev/min) & $\begin{array}{c}\text { Feed rate } \\
(\mathbf{m m} / \mathbf{r e v})\end{array}$ & \multicolumn{3}{|c|}{$\begin{array}{c}\text { Process } \\
\text { time } \mathbf{t}_{\mathbf{p}} \text { min }\end{array}$} & Remarks \\
\hline 220 & $200 \sim 600$ & 0.2 & 3.4 & 4.4 & 4.6 & In Range \\
\hline 220 & $200 \sim 600$ & 0.25 & 3.05 & 4.15 & 3.8 & In Range \\
\hline 220 & $200 \sim 600$ & 0.3 & 2.56 & 2 & 1.9 & out of Range \\
\hline 220 & $200 \sim 600$ & 0.35 & 6.02 & 2.95 & 2.5 & out of Range \\
\hline 220 & $200 \sim 600$ & 0.4 & 3.56 & 4.78 & 5.15 & In Range \\
\hline 220 & $200 \sim 600$ & 0.45 & 2.43 & 2 & 6.85 & out of Range \\
\hline
\end{tabular}

Table 11: Feed rate and surface roughness at constant RPM.

\begin{tabular}{|c|c|c|c|c|c|c|}
\hline $\begin{array}{c}\text { Job } \\
\text { dia }\end{array}$ & RPM (rev/min) & $\begin{array}{c}\text { Feed rate } \\
\text { (mm/rev) }\end{array}$ & \multicolumn{3}{|c|}{$\begin{array}{c}\text { Surface roughness } \\
\text { (mm of turning) } \boldsymbol{\mu m}\end{array}$} & Remarks \\
\hline 220 & $400 \sim 1200$ & 0.1 & 0.54 & 1.19 & 1.78 & In Range \\
\hline 220 & $400 \sim 1200$ & 0.15 & 0.85 & 1.27 & 1.89 & In Range \\
\hline 220 & $400 \sim 1200$ & 0.2 & 1.01 & 2.5 & 2.34 & out of Range \\
\hline 220 & $400 \sim 1200$ & 0.25 & 1.15 & 2.34 & 2.67 & out of Range \\
\hline 220 & $400 \sim 1200$ & 0.3 & 0.98 & 1.56 & 1.43 & In Range \\
\hline 220 & $400 \sim 1200$ & 0.35 & 2.43 & 1.95 & 1.8 & out of Range \\
\hline
\end{tabular}

Table 12: Feed rate and surface roughness at constant RPM.

\begin{tabular}{|c|c|c|c|c|}
\hline \multicolumn{5}{|c|}{ Calculation of DOC (constant feed rate) } \\
\hline Job dia & Feed & DOC & Surface finish, $\boldsymbol{\mu m}$ & Remarks \\
\hline 220 & 0.3 & 0.2 & 4 & Accepted \\
\hline 220 & 0.3 & 0.24 & 4.15 & Accepted \\
\hline 220 & 0.3 & 0.28 & 3.58 & Accepted \\
\hline 220 & 0.3 & 0.32 & 5.54 & Accepted \\
\hline 220 & 0.3 & 0.38 & 2.91 & Not Accepted \\
\hline 220 & 0.3 & 0.4 & 2.54 & Not Accepted \\
\hline 220 & 0.3 & 0.45 & 2.32 & Not Accepted \\
\hline 220 & 0.3 & 0.5 & 2.54 & Not Accepted \\
\hline 220 & 0.3 & 0.55 & 2.6 & Not Accepted \\
\hline 220 & 0.3 & 0.6 & 2.3 & Not Accepted \\
\hline
\end{tabular}

Table 13: DOC and surface finish for process $D_{1}$.

Surface finish is within the acceptable range ( 3 to $6 \mu \mathrm{m}$ ) as increase DOC values $0.2,0.24,0.28$ and 0.32 . DOC value of 0.28 is nominated because at this point the surface is at the lowest range of surface finish requirement. 
Citation: Manzoor T, Khali S, Khan I, Gohar GA, Abid M (2017) Design and Development of Flexible Vacuum Clamping System for Thin Walled Cylindrical Object for CNC Machines. J Appl Mech Eng 6: 271. doi: 10.4172/2168-9873.1000271

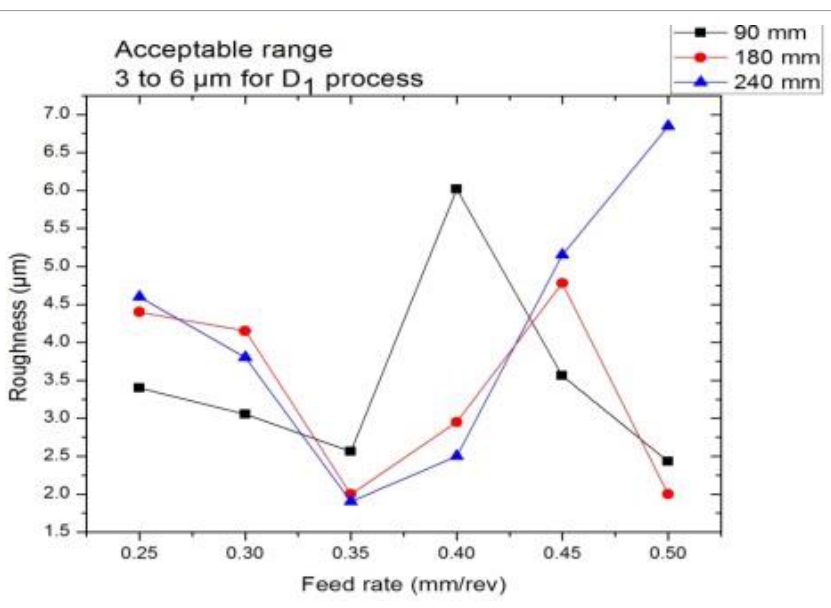

Figure 14: Feed rate versus surface roughness for process D1.

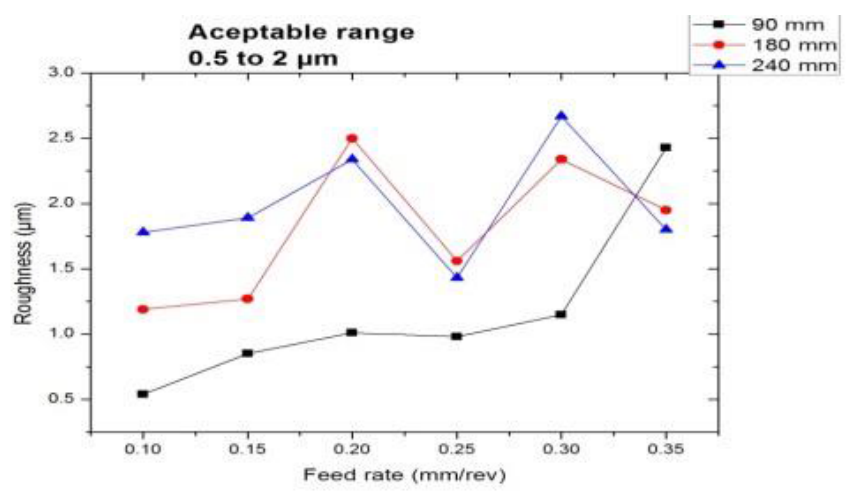

Figure 15: Feed rate versus surface roughness for process $C 1$.

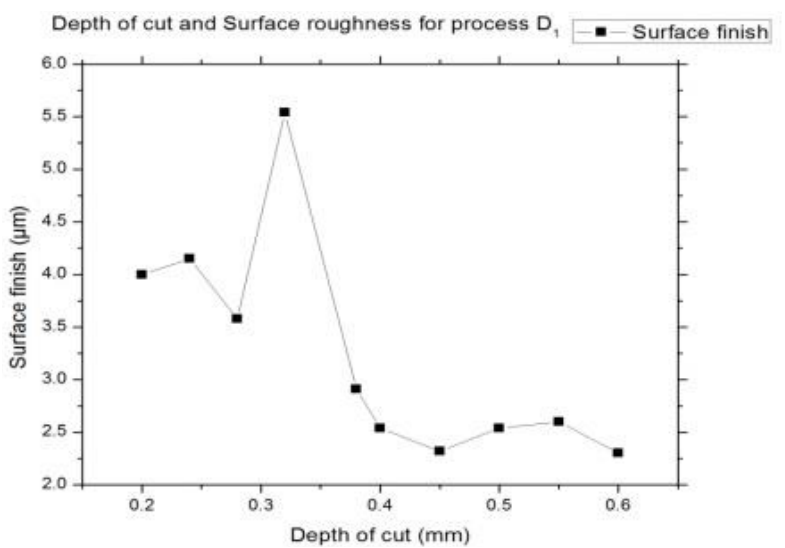

Figure 16: Surface finish and DOC for process D1.

Optimum depth of cut for process C1: At constant feed rate, Surface finish changes with variation of depth of cut from 0.1 to 0.4 .

Surface finish is within the acceptable range ( 0.5 to $2 \mu \mathrm{m})$ as increase DOC values of $0.1,0.14,0.18$ and 0.2 . DOC value 0.18 is selected because at this point the surface is at the average range of surface finish requirement (Tables 14 and 15).

\section{Optimum vacuum pressure for process $D_{1}$}

At $0.28 \mathrm{~mm}$ DOC value, the vacuum pressure varies from $15 \mathrm{KPa}$

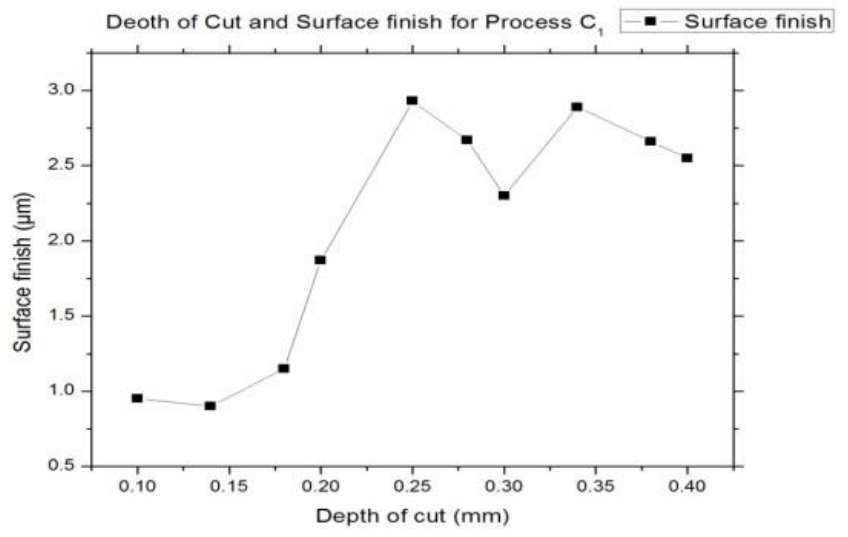

Figure 17: Surface finish and DOC for process $\mathrm{C} 1$.

\begin{tabular}{|c|c|c|c|c|}
\hline \multicolumn{5}{|c|}{ Calculation of DOC (Constant feed rate) } \\
\hline Job dia & Feed & DOC & $\begin{array}{c}\text { Surface finish, } \\
\boldsymbol{\mu m}\end{array}$ & Remarks \\
\hline 220 & 0.3 & 0.1 & 0.95 & Accepted \\
\hline 220 & 0.3 & 0.14 & 0.9 & Accepted \\
\hline 220 & 0.3 & 0.18 & 1.15 & Accepted \\
\hline 220 & 0.3 & 0.2 & 1.87 & Accepted \\
\hline 220 & 0.3 & 0.25 & 2.93 & Not accepted \\
\hline 220 & 0.3 & 0.28 & 2.67 & Not accepted \\
\hline 220 & 0.3 & 0.3 & 2.3 & Not accepted \\
\hline 220 & 0.3 & 0.34 & 2.89 & Not accepted \\
\hline 220 & 0.3 & 0.38 & 2.66 & Not accepted \\
\hline 220 & 0.3 & 0.4 & 2.55 & Not accepted \\
\hline
\end{tabular}

Table 14: $D O C$ and surface finish for process $C 1$.

\begin{tabular}{|c|c|c|c|}
\hline \multicolumn{4}{|c|}{ Calculation of vacuum pressure required } \\
\hline Job dia & DOC & $\begin{array}{c}\text { Vacuum } \\
\text { pressure (KPa) }\end{array}$ & Results/Remarks \\
\hline 220 & 0.28 & 15 & Clamping not sufficient \\
\hline 220 & 0.28 & 30 & Poor visual surface texture \\
\hline 220 & 0.28 & 60 & Excessive wear of tool bit \\
\hline 220 & 0.28 & 85 & Excellent \\
\hline 220 & 0.28 & 90 & Poor dimensional accuracy \\
\hline 220 & 0.28 & 100 & Poor dimensional accuracy \\
\hline
\end{tabular}

Table 15: Evaluating vacuum pressure for $D_{1}$

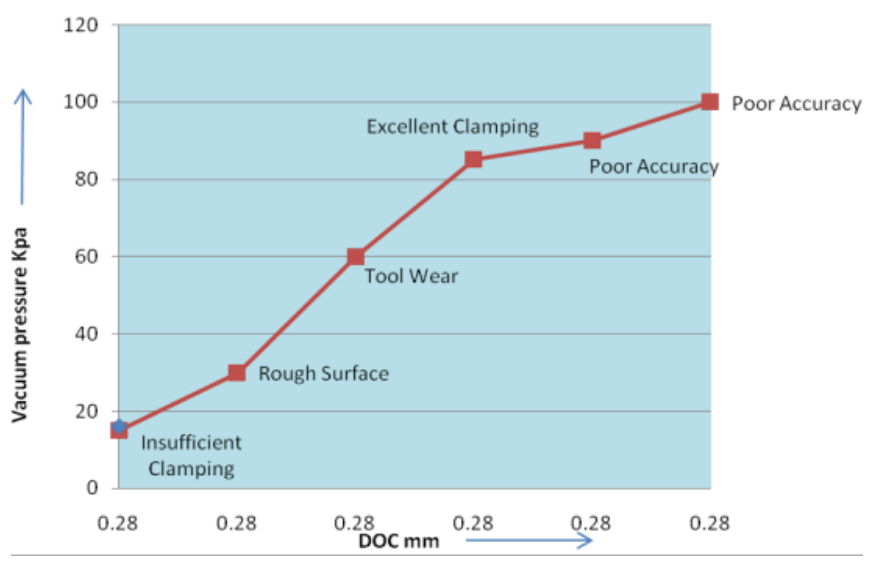

Figure 18: Graphical representation. 
Citation: Manzoor T, Khali S, Khan I, Gohar GA, Abid M (2017) Design and Development of Flexible Vacuum Clamping System for Thin Walled Cylindrical Object for CNC Machines. J Appl Mech Eng 6: 271. doi: 10.4172/2168-9873.1000271

to $100 \mathrm{KPa} .85 \mathrm{KPa}$ vacuum clamping pressure gives excellent results in vacuum clamping system of manufacturing.

\section{Conclusion}

The present study shows that importance of vacuum clamping system for massive production with great accuracy and dimension tolerance. This research was carried out thin walled job that is difficult to do machine using conventional manufacturing process. It is concluded that new flexible clamping system is better in different ways.

- Better control feed rate for purpose to obtain required surface finished jobs.

- To avoid severe deflection surface during inner and outer machining by vacuum clamping system. Figure 12 ANSYS give better result as compared to Figure 9.

- To save materials in which materials thickness reduced from $40 \mathrm{~mm}$ to $10 \mathrm{~mm}$.

- Less material removal that caused the greater tool life.

- Depth of cut (DOC) improved from 0.1 to 0.18 for process $\mathrm{C} 1$ and 0.2 to 0.28 for process D1.

Feed rate improved from 0.1 to 0.3 for process $\mathrm{C} 1$ and 0.25 to 0.4 for process D1.

\section{Conflict of Interest Statement}

It is acknowledged here that research work supported by the Department of Mechanical and Aeronautical Engineering UET Taxila, Pakistan and Department of Mechanical Engineering, COMSATS Institute of Information Technology, Sahiwal, Pakistan. There is no conflict of interest in this work. The author of this publication receives research support from their respective institutes. All authors are employers of these two institutes. We declare no conflict of interest in publishing this work.

\section{References}

1. Beeding JD (1988) Programmable vacuum pod system for chucking workpieces. Google Patents.

2. Rensch LA (1996) Method for holding a workpiece by vacuum. Google Patents.
3. Nichols JD (1995) Vacuum chuck for lathe. Google Patents.

4. Akre B (2004) Positionable vacuum clamp system. Google Patents.

5. Alquraan T, Kuznetsov Y, Tsvyd T (2016) High-speed clamping mechanism of the $\mathrm{CNC}$ lathe with compensation of centrifugal forces. Procedia Engineering 150: 689-695.

6. Deng $\mathrm{H}$, Melkote SN (2006) Determination of minimum clamping forces for dynamically stable fixturing. International Journal Mach Tools Manufact 46: 847-857.

7. Yang K, Guan S, Wang C (2011) The design and calculation for hydraulic cylinder of workpiece hydraulic clamping system of a special CNC machine for guide disc. Procedia Engineering 16: 418-422.

8. Zhu S, Ding G, Ma S, Yan K, Qin S (2013) Workpiece locating error prediction and compensation in fixtures. Int J Adv Manuf Tech 67: 1423-1432.

9. Wang J, Zhang J, Feng P, Wu Z, Zhang G (2015) Modeling and simulation for the critical bending force of power chucks to guarantee high machining precision. Int J Adv Manuf Tech 79: 1081-1094.

10. Feng P, Yu D, Wu Z, Uhlmann E (2008) Jaw-chuck stiffness and its influence on dynamic clamping force during high-speed turning. Int $\mathrm{J}$ MachTools and Manufact 48: 1268-1275.

11. Saravanan R, Sankar S, Asokan P, Vijayakumar K, Prabhaharan G (2005) Optimization of cutting conditions during continuous finished profile machining using non-traditional techniques. Int J Adv Manuf Tech 26: 30-40.

12. Sharma K, Mahto D, Sen S (2013) In metal turning, effect of various parameters on cutting tool: A Review. Int Journal of Application or Innovation in Engineering \& Management (IJAIEM).

13. Kumar NS, Shetty A, Shetty A, Ananth K, Shetty H (2012) Effect of spindle speed and feed rate on surface roughness of carbon steels in CNC turning. Procedia Engineering 38: 691-697.

14. Gupta R, Diwedi A (2014) Optimization of surface finish and material removal rate with different insert nose radius for turning operation on CNC turning center. International Journal Innovative Research in Science, Engineering and Technology 3: 13540-13547.

15. Reddy MR, Kumar PR, Rao GKM (2011) Effect of feed rate on the generation of surface roughness in turning. International Journal Engineering Science and Technology (IJEST).

16. Ince MA, Asiltürk I (2015) Effects of cutting tool parameters on surface roughness.

17. Atta CMV (1960) The design of high vacuum systems and the application of kinney high vacuum pumps. 